\title{
God's Consistency Which Is Promised Through a New-Normal-Era Health Protocol in Order to Preserve The Essence Of Humanity
}

\author{
Lister Napitupulu \\ Sekolah Tinggi Teologi Baptis Indonesia (STBI) Semarang, Indonesia \\ email: listernapitupulu@stbi.ac.id
}

\begin{abstract}
Health anthropology has experienced a tremendous new revolution, started from last year, 2020. A New-normal Health Protocol formulation was put in place to deal with the Covid-19 pandemic outbreak. Natural and social media communities complained about humanity and human rights degradation, raising calls for resistance due to imposed global restrictive regulations. God in Christian theology is a God who promises to His human creation that He will be with and help humans to have a happy and prosperous life. By doing literature research, this paper tries to explore whether the Covid-19 management guidelines are by the consistency of covenant God in restoring the essence of humanity. How is the relation between two paradigms of society, from God's side and human's side, through the Health Protocol intervention? The finding is that God, who created perfect human beings, keeps all the processes of his life to become the people of His eternal kingdom. Society and individuals should be able to respond to global regulations as support for faith and perspective to continue to live and fill the days ahead with the maximum quality of life as prime human beings.
\end{abstract}

Keywords: God's covenant, health protocol, new-normal, humanity

\begin{abstract}
ABSTRAK: Antropologi kesehatan mengalami suatu revolusi baru yang dahsyat, dimulai dari tahun lalu, 2020. Sebuah rumusan Protokol Kesehatan New-normal diberlakukan untuk menangani wabah pandemi Covid-19. Masyarakat nyata dan media sosial mengeluhkan perasaan degradasi kemanusiaan dan hak asasi manusia bahkan mencuatkan seruan perlawanan karena peraturan pembatasan global yang dipaksakan. Allah dalam teologi Kristen adalah Allah yang berjanji kepada manusia ciptaan-Nya bahwa Ia akan menyertai dan menolong manusia untuk mendapatkan kehidupan yang sejahtera dan berbahagia. Dengan melakukan sebuah literature-research tulisan ini mencoba menelusuri apakah pedoman tatalaksana Covid19 ini sesuai dengan konsistensi Allah yang berjanji dalam hal memulihkan esensi kemanusiaan. Bagaimanakah hubungan antara dua paradigma tentang kemanusiaan dari sisi Allah dan manusia melalui intervensi Protokol Kesehatan. Temuan bahwa Allah yang menciptakan manusia yang sempurna menjaga sepanjang proses kehidupannya agar menjadi umat kerajaan kekal-Nya. Seyogyanya masyarakat dan individu dapat menyikapi peraturan global sebagai penopang iman dan cara pandang sehingga tetap dapat menjalani dan mengisi hari-hari ke depan dengan kualitas hidup maksimal sebagai manusia prima.
\end{abstract}

Kata Kunci: Allah berjanji, protokol kesehatan, new-normal, kemanusiaan.

Article History: Submitted: 11 Februari 2021

Revised: 19 Juli 2021

Published: 29 Juli 2021

\section{PENDAHULUAN}

Sudah lebih dari satu tahun wabah pandemi Covid-19 melanda seluruh dunia (Yuliana, 2020). Ini adalah wabah terluas yang menjangkau hampir 250 negara yang ada di planet bumi ini (Siagian, 2020). Covid-19 situation update worldwide, tertanggal 29 Oktober 2020, mencatat 1,2 juta kasus kematian dari 45 juta kasus terjangkit Covid-2019 (European
Centre for Disease Prevention and Control, 2020). Di Indonesia sendiri, jumlah terpapar Covid-19 404.048 kasus positif dengan 13.701 kematian (Ramadhan, 2020). Dampak terberat yang dialami seluruh negara secara global adalah stagnasi kegiatan usaha hampir di segala bidang yang menyebabkan resesi ekonomi (Wuryandani, 2020). Banyak organisasi perusahaan dan pelaku bisnis terhenti dan jatuh bangkrut akibat 
kondisi akut progresif ini (Indonesia, 2020). Pada bidang pelayanan kesehatan pun terjadi perubahan besar-besaran sistem penanganan kesehatan akibat munculnya wabah pandemi Covid-19 ini (Dirjen Pencegahan dan Pengendalian Penyakit, 2020). Protokol kesehatan dicanangkan menjadi peraturan yang sangat ketat dan era New-normal diserukan sebagai tata cara hidup baru yang diperbolehkan (Menpan.go.id, 2020). Semua kantor pemerintah dan swasta, para karyawan dan pekerja diwajibkan mematuhi protokol baru ini. Peraturan utama adalah setiap orang wajib memakai masker, mencuci tangan, menjaga jarak (physical distancing), dan menghindari kerumunan (social distancing). Work from house dan seruan \#dirumahsaja dikumandangkan.

Dalam praktiknya di masyarakat muncul larangan melakukan kegiatan yang mengumpulkan banyak massa, seperti resepsi perkawinan, upacara penguburan kematian, dan melakukan ritual ibadah agama di tempat-tempat peribadahan seperti biasanya. Tempat-tempat hiburan ditutup, transportasi udara, laut, dan darat untuk publik dihentikan, mengunjungi orang sakit ke rumah sakit juga tidak diperbolehkan. Kelompok usia lanjut dan anak-anak dicegah dan tidak dianjurkan mengikuti pelaksanaan ibadah, baik yang ke masjid, gereja, pura, atau tempat ibadah umum lainnya (Nurita, 2020), ke tempat perbelanjaan (Abdul \& Fahmi, 2020), atau saling berkunjung sebagai anggota keluarga, bersaudara, ataupun teman. Bagi individu yang dalam operasi satuan pengawas ditemukan pelanggaran dengan tidak memakai masker akan segera mendapatkan sanksi hukum. Sarana mencuci tangan dengan sangat mudah ditemukan dihalaman-halaman bagaikan jamur yang tumbuh di musim penghujan. Ditawarkan berbagai bentuk alat perlindungan diri seperti masker, faceshield, tutup kepala, kacamata, hand-sanitizer, apron, hazmat, sepatu boot, dsb. Manusia-manusia di mediasosial internet berkeluh tentang merasakan degradasi kemanusiaan dan hak asasi bersosialisasi, bahkan ada yang menyerukan perlawanan terhadap prosedur standar operasional pemerintah sehubungan penang- gulangan penyebaran Covid-19 (Kompas.com, 2020).

Tulisan ini membahas tentang dua pertanyaan yaitu bagaimanakah perspektif teologi memandang realita ini? Dan apakah Allah yang berjanji menurut teologi alkitabiah masih konsisten dengan sifat dan hakekat-Nya dalam masa pandemi yang memberlakukan Protokol era New-normal ini? Penulis melakukan literature-research untuk menemukan jawaban pertanyaan ini. Tujuan penulis adalah untuk menemukan konsistensi Allah yang berjanji terhadap manusia yang diciptakan-Nya segambar dan serupa dengan-Nya dalam hal menangani masalah wabah pandemi Covid-19. Selanjutnya penulis ingin mendapatkan anjuran praktis bagi masyarakat ekonomi, sosial dan individu dalam menyikapi protokol era New-normal saat kini dan kemudian.

\section{METODE}

Tulisan ini berlandaskan pada pemikiran paradigm postpositivisme dan menggunakan metode literature-research (Hamzah, 2020, pp. 3-39). Alkitab, buku-buku teologi, artikel jurnal Kristen dan informasi-informasi publik terkait topik digali sebagai sumber-sumber utama (Darmawan \& Asriningsari, 2018; S. E. Zaluchu, 2020, 2021). Allah yang berjanji ditelusuri rentetan rencana dan perbuatan-Nya untuk mempertahankan harkat kemanusiaan tetap eksis pada manusia sebagaimana hakekatnya. Perkembangan antropologi kesehatan ditelusuri khususnya dalam hal revolusi penanganan masalah kesehatan karena wabah pandemi Covid-19. Hubungan antara dua paradigma dari sisi Allah dan manusia mengenai esensi kemanusiaan ditelusuri melalui intervensi Protokol Kesehatan New-normal. Penelusuran dilakukan secara deskriptif kualitatif hingga pada kesimpulan memberikan saran kemanusiaan bagi manusia sedemikian sebagaimana sejatinya.

\section{HASIL DAN PEMBAHASAN}

Dalam rancangan Allah yang sempurna manusia diciptakan segambar dan serupa dengan-Nya pada hari yang keenam ihwal penciptaan (Alkitab 
Kejadian 1) Keserupaan dengan Allah meliputi aspek rohaniah, mental, moral, dan sosial, tetapi tidak fisikal (Thiessen, 1989, pp. 151-157). Selain itu, manusia diperlengkapi dengan semua keperluan, tempat di alam semesta dan seluruh isinya, tata cara hidup, dan teman penolong yang sepadan dengan manusia itu sendiri. Dalam perjalanannya, manusia berkembang dalam segala aspek dari makhluk primitif hingga kini menjadi makhluk modern yang sangat kompleks (Ruswanto, 2016). Perubahan-perubahan silih berganti dan turun-naik kondisi adopsi dan adaptasi manusia terhadap Allah, alam, dan sesama, hal ini berpengaruh terhadap kondisi evolusi perkembangan bangunan hidup selanjutnya (Siregar, 2002). Tetapi Allah dalam hakekat-Nya tetap berinisiatif terlibat dalam keseluruhan hidup manusia sebagai makhluk umat pilihan yang dipelihara dan dikasihi-Nya (Erickson, 2003, p. 47). Di sisi lain, keterbatasan yang ditandai dengan wujud fisik yang terlokalisir menandakan kespesialan manusia juga sebagai ras dan spesies manusia dalam rancangan penciptaan. Keterbatasan tersebut meliputi semua aspek kehidupan manusia juga terutama dalam kehidupan jasmaniah yang kasat mata. Hal itu bertautan dengan rencana Allah untuk selalu dapat berada dalam hubungan yang tak terpisahkan antara manusia dengan Allah yang tidak terbatas. Kehendak Allah adalah untuk selalu terlibat bagi kebaikan dan kesempurnaan manusia.

\section{Konsistensi Allah}

Ketika manusia jatuh ke dalam dosa, Allah mengampuni dan memperbaiki kehidupan manusia, namun kembali keturunan manusia terjerumus pada kejahatan dan kefasikan, sehingga Allah membasmi manusia dari muka bumi dengan peristiwa air bah. Babak baru kehidupan melalui keturunan nabi Nuh diawali, tetapi Alkitab mencatat kejahatan dan pemberontakan terhadap Allah terulang lagi. Kesatuan yang dibayangkan oleh keturunan Nuh untuk manfaat kemudahan bagi mereka melakukan kehendak sendiri, diserakkan Allah dengan mengacaukan bahasa dan membuat mereka tidak mengerti satu sama lain.
Kembali Allah merancang hidup manusia melalui kisah Abraham, dengan berjanji, "Aku akan memberkati orang-orang yang memberkati engkau, dan mengutuk orang-orang yang mengutuk engkau, dan olehmu semua kaum di muka bumi akan mendapat berkat." Zaluchu (2017) mengatakan bahwa Alkitab memberitahukan tentang Allah yang berjanji (God's covenant). Allah membuat perjanjian di taman Eden kepada manusia sebagai wakil Allah atas seluruh ciptaan-Nya. Allah berjanji kepada Adam yang jatuh berdosa menyangkut cara mempertahankan hidup dengan bekerja keras. Allah juga berjanji kepada Nuh akan diberkati dengan hidup benar di hadapan Allah, dan kepada Abraham akan memberikan tanah Kanaan, memberkatinya, keturunannya, dan segala bangsa di muka bumi. Secara progresif Allah membuat perjanjian kepada bangsa Israel, kepada Daud, dan melalui nabi Yeremia sebuah Perjanjian baru kepada Israel dan Yehuda. Sebagai akibat dosa, maka kutuk, sakit, kematian, kekalahan, menjadi bagian dari kemanusiaan. Tetapi Allah akan melakukan tindakan pemulihan dan penyembuhan kembali kondisi kesakitan dan kehancuran akibat ketidaktaatan mereka. Tuhan Allah akan selalu menolong dan memulihkan umat tebusan-Nya dari dosa, kelemahan, kesusahan, penderitaan dan lelah perjuangannya. Alkitab berbicara tentang Allah akan menegakkan Kerajaan-Nya yang kekal sampai selama-lamanya, bersama para orang-orang-Nya yang percaya dan yang dibenarkan oleh darah Yesus (Enns, 2003, p. 39).

Allah mengutus Yesus sebagai teladan dan gambar manusia yang sempurna, yang tidak berdosa. Dalam hal sebagai manusia, Ia menerapkan praktik hidup secara aktual di dunia. Kesempurnaan itu meliputi memiliki persekutuan yang sempurna dengan Allah Bapa, mentaati kehendak Bapa, memperlihatkan kasih yang kuat terhadap manusia, terikat satu sama lain dengan umat manusia di dalam kasih. Maiaweng (2015), menjabarkan kemanusiaan Yesus yang sempurna melalui kelahiran-Nya, memiliki darah dan daging manusia, dapat dilihat, disentuh, hidup dalam dunia yang berdosa tetapi tidak melakukan dosa, dan mengambil bagian dalam penderitaan manu- 
sia. Dalam hal berelasi sosial Yesus mengerjakan pelayanan-Nya, mengajar, menyembuhkan yang sakit, mengalami penderitaan, penyaliban, dan kematian. Lebih lanjut, Tumbel (2016) merinci kemanusiaan sejati Yesus dalam hal garis keturunan manusia-Nya, kelahiran dan masa kanak-kanak-Nya, status-Nya yang rendah, menyesuaikan diri dengan tradisi orang Yahudi, mengalami pencobaan, mengatur kapal-kapal nelayan, membayar pajak, berbicara kepada orang yang berbeda, berkeringat darah, menangis karena ditinggalkan di atas kayu salib, semua mencerminkan kemanusiaan Yesus. Dalam hal penderitaan Yesus, Zaluchu (2017) menyatakan, adalah wujud solidaritas Allah kepada manusia, dimana dosa manusia menyebabkan Allah dalam kasih-Nya mengalami penderitaan fisik sebagai manusia $100 \%$ melewati jalan salib (via dolorosa). Zaluchu (2017) memandang bahwa penderitaan yang dialami Yesus adalah sebagai bukti Tuhan bekerja bukan hanya dalam beberapa hal, tetapi dalam segala sesuatu oleh karena kedaulatan-Nya, sesuai kehendak-Nya sendiri, bahwa seperti apapun penyebab penderitaan menimbulkan rasa sakit fisik dan emosional pada manusia, semua itu tidak akan pernah melampaui kedaulatan Allah. Kehadiran Yesus di muka bumi adalah rancangan Allah yang sempurna untuk menjadi manusia contoh teladan dan bukti faktual bagi manusia sampai masa kini.

\section{Interaksi Allah melalui Protokol Kesehatan}

Sejarah mulai mencatat berkembangnya sebuah bidang ilmu Antropologi Kesehatan tahun 1945. Walaupun persoalan antropologi kesehatan sebenarnya telah muncul jauh sebelum menjurus menjadi suatu bidang ilmu. Antropologi Kesehatan, seperti dikutip dari Solita Sarwono, 1993 adalah studi tentang pengaruh unsur-unsur budaya terhadap penghayatan masyarakat tentang penyakit dan Kesehatan (Sukma, 2015). Definisi yang dirinci oleh Foster dan Anderson (1986) adalah yang memberi perhatian pada aspek biologis dan sosial budaya dari tingkah laku manusia, terutama tentang cara-cara interaksi antara keduanya di sepanjang sejarah kehidupan ma- nusia, yang mempengaruhi kesehatan dan penyakit pada manusia (Djhot, 2002). Lebih lanjut Indirawaty et al. (2017), menjelaskan bahwa penyakit dalam beberapa bentuk merupakan kenyataan universal dari kehidupan manusia, ini terjadi dalam keseluruhan waktu, tempat dan masyarakat. Kelompok manusia mengembangkan metode dan peran-peran yang teralokasi, sama dengan sumber daya dan struktur mereka untuk meniru dengan atau merespon penyakit. Kelompok manusia mengembangkan beberapa set kepercayaan, pengertian dan persepsi yang konsisten dengan matriks budaya mereka, untuk menentukan atau menyadari penyakit. Tingkah laku sakit, peranan sakit, dan peranan pasien sangat dipengaruhi oleh faktor kelas sosial dan perbedaan suku bangsa dan budaya.(MRL, Jaya, \& Mahendra, 2019, pp. 4-28) Maka ancaman kesehatan yang sama (yang ditentukan secara klinis) bergantung dari variable-variabel tersebut dapat menimbulkan reaksi yang berbeda di kalangan pasien. Hubungan perubahan biologi yang terjadi dengan faktor sosial budaya, misalnya Albinisme di NTT yang ditransmissikan melalui gen resesif karena pernikahan anggota keluarga (Indirawaty et al., 2017). Pandangan dunia yang berbeda (gaib, religi, dan naturalis) menghubungkan sistem kepercayaan dan menciptakan model perilaku medis yang sesuai. Antropologi kesehatan memberikan cara untuk memandang masyarakat secara keseluruhan termasuk individunya (Husaini, Rahman, \& Marlinae, Lenie, 2017, pp. 47-77). Cara pandang yang tepat akan memberi kontribusi yang tepat dalam meningkatkan kesejahteraan suatu masyarakat dengan tetap bertumpu pada akar kepribadian masyarakat yang membangun.

Wabah pandemi dicatat telah berkali-kali terjadi. Flu Burung tahun 1874 dari Italia sampai ke AS, Hongkong, dan Indonesia. Flu Babi, Cacar Monyet, SARS-CoV 2002 dengan kematian 777 jiwa (10\% dari kasus), Ebola 2014 kematian 11.310 jiwa (25-90\% tingkat kematian saat wabah), dan MERS 2012 menyebabkan 858 kematian (dengan tingkat kematian 37\%). Covid-19 menyebabkan tingkat kematian 2-3\% (Asian Development Bank, 2020). Pe- 
nanganan masalah wabah pandemi terus berkembang semakin lebih baik seiring semakin meningkatnya ilmu pengetahuan dan teknologi. Tampaknya kematian akibat Covid-19 sangat kecil persentasinya dibanding peristiwa wabah-wabah penyakit sebelumnya, 2\% kasus. Dalam menangani wabah Covid-19 telah dicanangkan prosedur protokol kesehatan sebagai yang paling ampuh. Keputusan ini bukan lahir begitu saja dengan mudah. Tetapi dengan penyelidikan, penelitian, dan kerja keras semua pakar kesehatan bekerja sama dengan semua elemen pemerintah dan sumber-sumber informasi terkait ("Coronavirus Disease (COVID-19),” 2020). Masih terekam suasana mencekam dan menggemparkan di awal tahun 2020 munculnya wabah, terjadi ketakutan dan kepanikan dunia, chaos berita, saling curiga antar negara, dan kebingungan di masyarakat. Dengan tekanan dan tuntutan yang kuat akan kebutuhan perlindungan dan perlawanan terhadap Covid-19, akhirnya dirumuskan suatu tata cara New-normal dengan standar Protokol Kesehatan di semua lini kegiatan pemerintah, kantorkantor, dan masyarakat, termasuk di rumah sakit dan layanan kesehatan lainnya.

Protokol Kesehatan tidak sesederhana 4M (memakai masker, mencuci tangan, menjaga jarak, menghindari kerumunan) yang dikampanyekan di seluruh lapangan masyarakat. Pedoman penatalaksanaan pandemi tersebut mencakup semua prosedur yang harus dikerjakan di semua tingkat keparahan pasien Covid-19 di semua tingkat layanan kesehatan. (Kesehatan RI, 2021) Protokol New-normal juga menetapkan garis-garis yang harus dipedomani oleh semua unit pelayanan publik baik di daerah (Rohman \& Larasati, 2020) dan secara global internasional (Pura, 2020). Tim-tim pemantauan, pengawas, satuan tugas dan evaluasi pelaksanaan, efektifitas, hasil, dan kondisi terkini bekerja dalam koordinasi satu garis (Umagapi \& Sanur L, 2020). Strategi penanganan pencegahan penularan Covid-19 meliputi pengharusan, himbauan, pemantauan oleh satuan petugas, dan juga dukungan, propaganda, sosialisasi-persuasi dari para sukarelawan di semua tempat.(Irawan, Triana, Suwarni, \& Selviana, 2020) Bukan hal yang mudah, tetapi telah dapat dilaksanakan. Penghargaan dan dukungan untuk keberhasilan protokol kesehatan patut diberikan oleh setiap individu dan masyarakat.

\section{Hubungan Dua Paradigma}

Satu sisi pandangan masyarakat mengatakan bahwa Protokol Kesehatan dengan praktik pembatasan sosial adalah tidak manusiawi (HAM RI, 2020). Letak nilai ketidakmanusiawian ini seharusnya perlu lebih dikritisi. Misalnya, mencuci tangan sesering mungkin memang merepotkan tetapi lebih bermuatan budaya sehat. Hal ini sejak lama telah diterapkan sebagai standar akreditasi di tempat-tempat pelayanan kesehatan, seperti rumah sakit dan Puskesmas. Gaya hidup mencuci tangan sebelum dan sesudah menyentuh sesuatu perlu dibiasakan sekalipun bukan karena wabah pandemi. Dalam Alkitab tampak bahwa mencuci tangan adalah budaya hidup orang Yahudi dan bertujuan untuk menjaga kemurnian hidup (Matthew, 2019). Mencuci tangan dapat menjadi ekspresi hati manusia yang bersih, sehingga terus menjaga kebersihan badaniah (Simorangkir, 2020). Kejadian wabah telah menjadi titik awal langkah memasyarakatkannya. Dalam hal physical distancing dan social distancing yang dirasakan menghalangi manifestasi kemanusiaan, adalah sebagai akibat dan respon gelora $i d$ dan ego manusia yang menjadi naik meningkat dan membutuhkan wadah pemuasan (Hamali, 2018; lihat tentang id dan ego pada Wijaya \& Darmawan, 2019). Namun yang perlu dipahami adalah bahwa peraturan pembatasan yang dicanangkan oleh pemerintah bukan berarti pelarangan atau pemutusan sama sekali. Penulis berasumsi bahwa apabila sudut pandang penilaian cenderung pada pemenuhan tercapainya ambang kuantitas sosialisasi secara fisik, tentu akan terasa menyakitkan. Tetapi jika sudut pandang mengacu pada peningkatan bobot kualitas hubungan sosialisasi yang positif, maka sesama manusia justru akan menyadari dan semakin menghargai betapa mulianya hak azasi dan esensi kemanusiaan.(Novira, Iskandar, \& Bahraen, 2020, pp. 27-32) Demikian juga protokol isolasi mandiri dan hal perjalanan yang mewajibkan menyertakan 
surat keterangan telah menjalani pemeriksaan swab dengan hasil negatif, ada makna mulia yang tersirat di dalamnya, yaitu mengajak manusia untuk menghargai kemanusiaan sebagai hak azasi tertinggi.(Nadilla, 2020).

Surat Ibrani 1: 1-2 dalam Alkitab menuliskan bahwa sejak zaman dahulu Allah berulangkali dan dalam pelbagai cara berbicara kepada nenek moyang orang Israel dengan perantaraan nabi-nabi. Lalu pada zaman akhir ini Ia telah berbicara kepada umat-Nya dengan perantaraan Anak-Nya yang telah Ia tetapkan sebagai yang berhak menerima segala yang ada (Gea, 2018). Oleh Dia Allah telah menjadikan alam semesta. Dari Kitab Kejadian 9, dapat diketahui bagaimana Allah turun tangan, membuat janji, tetapi manusia jatuh bangun, taat dan melawan, sehingga menerima suka dan duka, kasih dan pukulan, bahagia diberkati dan hukuman kutuk. Mazmur 31: 1-6, Raja Daud bermazmur tentang campur tangan Allah yang setia bagi setiap orang, sejak dulu, sekarang dan seterusnya. Mazmur 3 dan 57 juga menunjukkan bahwa di tengah situasi krisis, Allah selalu memberikan kekuatan baru bagi umat-Nya (Mustika \& Objantoro, 2020a, 2020b). Ia Allah yang tetap setia pada janjiNya. Injil Matius 4:12-17 menunjukkan, dari waktu kehadiran Yesus di muka bumi sebagai manusia yang sempurna, pemulihan Kerajaan Allah dideklarasikan secara lebih intens. 1 Tesalonika 4:13-18, sampai pada hari dan waktunya Allah akan datang menjemput dan menegakkan kerajaan-Nya dengan umat manusia sebagai warga negaranya, Allah tidak berhenti menghibur dan mendukung umat-Nya dalam pengharapan dan iman percaya. Kitab Wahyu 21:1-4 mencatat, disana, di Yerusalem yang baru, berkumpul dan bertemunya Allah, malaikat, dan umat manusia, di sorga yang kekal. Tuhan Allah bekerja dan selalu berkehendak menata kembali dunia yang sehat, umat manusia yang beradab, dan mengembalikan manusia yang menyerupai gambar Allah, supaya menjadi manusia sejati.

Kehadiran Tuhan Yesus sebagai manusia yang membaur dengan manusia di muka bumi tidak disangkal lagi sebagai wujud karya Allah memu- lihkan kehancuran dan penderitaan manusia untuk dapat kembali berbahagia dalam hubungannya dengan Allah (Patandean, 2018). Napitupulu (2017), dalam tesisnya tahun 2017, menemukan pola dalam pelayanan Yesus menyembuhkan penderita penyakit-penyakit kronis. Bahwa Tuhan peduli terhadap penderitaan manusia, Tuhan memberikan harapan bagi manusia untuk sembuh, Tuhan tidak membedakan kondisi sosial ekonomi penderita, bahwa Yesuslah yang berperan dalam penyembuhan, Yesus mendasarkan pelayanan penyembuhan atas kasih kepada Tuhan dan sesama, pelayanan penyembuhan adalah sarana untuk menyatakan pekerjaan Allah, dan Yesus menghargai iman orang kepada-Nya (Napitupulu, 2017). Konsistensi Allah yang berjanji tampak dibarengi oleh keterlibatan semacam usaha keras dari pihak Allah menjaga alam semesta termasuk melalui delegasi mandat kepada manusia, sekaligus menjaga, memelihara, dan menyelamatkan umat manusia (Hannas \& Rinawaty, 2019). Mazmur 121 mengumandangkan Allah yang tidak pernah terlelap dan tertidur, Tuhan Penjaga umat manusia, keluar masuknya sampai selama-lamanya takkan pernah membiarkan.

Sebagaimana Allah memiliki kuasa, perasaan, kasih, pikiran, kehendak, relasi, dan moral, demikian makhluk ras manusia adanya, apalagi sebelum tanpa dosa. Manusia sebagai satu spesies khusus memiliki sifat, tugas, dan peranan yang khusus dan lengkap. Allah mengaruniakan kekuatan personalitas dan kepribadian yang memungkinkan manusia memuja dan melayani Allah pencipta. Ketika manusia menggunakan segenap kekuatan dan kemampuan untuk maksud tersebut, ia menjadi makhluk ciptaan yang telah melaksanakan kehendak-Nya dengan sempurna (Erickson, 2003). Sekalipun iblis berusaha dan terjun menebar tipu-daya, penderitaan dan sakit penyakit, tetapi Allah konsisten dengan kasih-Nya. Roma 8:28 dituliskan bahwa "Allah turut bekerja dalam segala sesuatu untuk mendatangkan kebaikan bagi orang yang mengasihinya." Era New-normal yang dirasakan sebagai penderitaan dan penjatuhan kondisi ke tingkat terendah sebenarnya di atasnya ada cara Allah memulihkan dan mempermudah umat- 
Nya bisa mengaktualisasikan iman, juga memulihkan dunia yang lebih baik, lebih sehat dan disegarkan, diperbaharui kembali (Eliasaputra, Novalina, \& Siahaan, 2020). Sehingga semua pihak baik yang bangkrut maupun yang justru berkembang pesat perusahaannya dari efek kondisi ini, semua menyadari Allah yang berperan dan berdaulat menata ulang bumi dan makhluk di dalamnya dibentuk, direformasi untuk suatu iklim, kondisi yang lebih sehat natural dan kembali kepada rancangan awal Allah (Sumakul, 2020). Bahwa dalam banyak hal Tuhan di atasnya menolong. Protokol kesehatan sebagai aturan global justru memulihkan keadaan alam dan budaya manusia.

Manusia diberikan keadaan yang dapat lebih mendekatkan dan memudahkan kepada kesempatan untuk dapat menyusun kehidupannya secara lebih maksimal untuk semakin mendekati pada tujuan Allah atas kemanusiaannya. Mengelola waktu dengan lebih berkualitas, membina hubungan komunikasi dan mengembangkan kasih yang tulus kepada Allah dan sesama. Memakai semua potensi dan talenta yang dimiliki untuk melakukan pekerjaan dan karya-karya terobosan yang memberkati dan membangun, membahagiakan pribadi, keluarga, saudara, sahabat, lingkungan sesama, bangsa dan negara, dan Tuhan secara simultan dan paralel.

Dalam wawancara oleh harian Kompas, Bambang PS Brodjonegoro, Menteri Riset dan Teknologi/ Kepala Badan Riset dan Inovasi Nasional, menyebutkan banyaknya inovasi yang justru muncul karena pandemi Covid-19, semua memberi solusi untuk menyelesaikan masalah kesehatan dan ekonomi bangsa, dengan hubungan yang sangat baik antara para ilmuwan, peneliti, dan industri, Indonesia sanggup memenuhi target inovasi dalam waktu singkat (Harian Kompas, 2020, p. 1). Sebuah harapan baru sesungguhnya terbuka untuk pemulihan tatanan ekonomi setelah pandemi. Seperti dikutip Trinugroho (2020), dari seorang Mazzucato, professor dari University College London, yang melihat peluang bernilai emas di balik krisis akibat pandemi. Dalam tulisannya yang dimuat majalah Foreign Affairs, bertajuk "Capitalism After the Pandemic", Mazzucato memberikan saran agar dana bantuan di masa krisis tidak salah mengalir kepada segelintir korporat raksasa tetapi lebih tepatnya kepada pertumbuhan ekonomi yang berkeadilan dan memberi kesejahteraan yang menjangkau sebanyak mungkin orang atau publik.(Trinugroho, 2020)

\section{SIMPULAN}

Allah pencipta langit dan bumi dan segala isinya adalah Allah yang berjanji dan konsisten dengan janji-Nya kepada umat manusia. Allah dalam teologi Kristen menjaga, menyertai, dan menolong umat-Nya agar mendapatkan kehidupan yang sejahtera dan berbahagia. Konsistensi Allah yang berjanji terbukti 'ya dan amen' dalam sepanjang perjalanan generasi ke generasi sampai pada era New-normal melalui peraturan global Protokol Kesehatan. Penanganan wabah pandemi Covid-19 dengan cara mensosialisasikan praktek 4M adalah bersesuaian dengan konsistensi Allah menghantarkan masyarakat dunia untuk menyadari harga dari esensi kemanusiaan. Tuhan Allah memberikan peluang dan memulihkan keadaan umat manusia untuk menemukan kembali harkat yang mulia dan sempurna seperti gambar dan rupa-Nya.

Kontroversi antara kecurigaan dan keyakinan masyarakat terhadap penetapan protokol New-normal masih saja berkumandang. Penelitian ini mendukung bahwa Allah melalui permakluman Protokol Kesehatan terlibat dalam pemulihan esensi kemanusiaan. Hal ini menunjukkan bahwa dalam masyarakat dunia yang semakin modernis dan hedonis sekalipun, justru eksistensi dan otoritas Allah semakin nyata perlu dipercaya dan merupakan kebutuhan terdepan. Teologi Kristen perlu terus digali dan dikembangkan sebagai jawaban terhadap setiap permasalahan.

Problem yang sulit dihadapi pemerintah dalam menangani wabah pandemi ini adalah tingginya persentasi kasus Covid-19, munculnya gelombang klaster baru, dan waktu kejadian yang berkepanjangan melampaui prediksi para ahli. Penelitian ini merekomendasikan penelitian lanjutan yang mene- 
mukan strategi-strategi solusi Alkitabiah yang dapat memberikan keberhasilan bagi pemerintah, bangsa dan dunia dalam menghadapi pandemi. Apakah isu semisal vaksinasi dan kebijakan multilateral yang baru hari-hari belakangan ini mulai dikumandangkan dalam pertemuan-pertemuan PBB (organisasi dunia,

\section{DAFTAR RUJUKAN}

Abdul, R., \& Fahmi. (2020). Pemkot Imbau Orang Tua Tak Ajak Anak-anak ke Mal di Kota Bandung. Pikiran-Rakyat.Com.

Asian Development Bank. (2020). Tingkat Kematian Lima Wabah di Dunia.

Coronavirus disease (COVID-19). (2020).

Darmawan, I. P. A., \& Asriningsari, A. (2018). Buku Ajar Penulisan Karya Ilmiah. Ungaran: Sekolah Tinggi Teologi Simpson.

Dirjen Pencegahan dan Pengendalian Penyakit, K. R. (2020). Pedoman Pencegahan dan Pengendalian Coronavirus Disease (Covid-19) (Revisi Ke). Jakarta: P2P Kemenenterian Kesehatan RI.

Djhot, D. R. (2002). Penerapan Ilmu Antropologi Kesehatan Dalam Pembangunan Masyarakat Papua. Antropologi Papua, 1(1), 11.

Eliasaputra, M. P., Novalina, M., \& Siahaan, R. J. (2020). Tantangan Pendidikan Agama Kristen Di Era Revolusi Industri 4.0 dan Pasca Kebenaran. BONAFIDE: Jurnal Teologi Dan Pendidikan Kristen, 1(1), 1-22. https://doi.org/10.46558/bonafide.v1i1.7

Enns, P. (2003). The Moody Handbook of Theology Jilid 1. Malang: Literatur SAAT.

Erickson, M. J. (2003). Teologi Kristen Volume Dua. Malang: Penerbit Gandum Mas.

European Centre for Disease Prevention and Control, A. A. of the E. U. (2020). Covid-19 situation update worldwide, ecdc.europe.eu/en/geographical-distribution2019-ncov-cases.

Foster, G. M., \& Anderson, B. G. (1986). Antropologi Kesehatan (Bahasa Ind). Jakarta: UI Press.

Gea, I. (2018). ALLAH MENJADI MANUSIA:
Perserikatan Bangsa Bangsa) bersesuaian dengan perintah Tuhan? Untuk penelitian lanjutan menarik juga untuk mencoba mengungkap hubungan antara tingkat kepercayaan individu dan komunitas dengan kejadian terkena serangan Covid-19 pada populasi tertentu.

Sebuah Uraian Teologis. KENOSIS: Jurnal Kajian Teologi, 2(2), 125-140. https://doi.org/10.37196/kenosis.v2i2.37

HAM RI, K. (2020). Keterangan PERS Himbauan Terbuka Komnas HAM RI Kepada Para Pihak Sehubungan dengan Penanganan Kasus-Kasus yang Diadukan Kepada Komnas HAM dalam Masa Pandemi Covid-19.

Hamali, S. (2018). Kepribadian Dalam Teori Sigmound Freud Dan Nafsiologi Dalam Islam. Al-Adyan: Jurnal Studi Lintas Agama, 13(2), 285-302.

https://doi.org/10.24042/ajsla.v13i2.3844

Hamzah, A. (2020). Metode Penelitian Kepustakaan

Library Research (Edisi Revi). Batu: Literasi Nusantara.

Hannas, H., \& Rinawaty, R. (2019). Apologetika Alkitabiah tentang Penciptaan Alam Semesta dan Manusia terhadap Kosmologi Fengshui sebagai Pendekatan dalam Pekabaran Injil. DUNAMIS: Jurnal Teologi Dan Pendidikan Kristiani, $\quad 4(1), \quad 55-74$. https://doi.org/10.30648/dun.v4i1.206

Harian Kompas. (2020). Wawancara Khusus, Menristek: Pandemi Picu Banyak Inovasi. Sabtu, 14 November 2020, p. 16.

Husaini, Rahman, F., \& Marlinae, Lenie, D. (2017). Antropologi Sosial Kesehatan (M. Saputra, Ed.). Banjarbaru: http://eprints.ulm.ac.id.

Indirawaty, AB, S., \& Sumarmi. (2017). Dasar-

Dasar Penerapan Antropologi Kesehatan. Ponorogo: WadeGroup.

Indonesia, C. (2020). Daftar Perusahaan Global yang Bakal Bangkrut karena Corona.

Irawan, D., Triana, N., Suwarni, L., \& Selviana, S. 
(2020). Edukasi Protokol Kesehatan Dan Strategi Pemasaran Online Melalui Program Kemitraan Masyarakat di Era Pandemi Covid19. Jurnal Masyarakat Mandiri, Vol. 4 No.

Kesehatan RI, K. (2021). Protokol Tatalaksana Covid-19 di Indonesia (Buku Saku). Jakarta.

Kompas.com. (2020). Hoaks Pernyataan Aliansi Dokter Sedunia Seputar Covid-19. Www.Kompas.Com.

Maiaweng, P. C. D. (2015). Inkarnasi: Realitas Kemanusiaan Yesus. Jurnal Jaffray, 13(1), 97120.

Matthew, H. (2019). Kitab Keluaran, Imamat. Surabaya: Momentum.

Menpan.go.id. (2020). Pencegahan Penyebaran Virus Covid-19 dengan Kerja di Rumah bagi ASN. Menpan.Go.Id.

MRL, A., Jaya, I. M. M., \& Mahendra, D. (2019). Antropologi Keperawatan. Jakarta: BMP.UKI, Jakarta.

Mustika, M. B., \& Objantoro, E. (2020a). Analisis Mazmur 3 Untuk Praktik Konseling Krisis. Kharisma: Jurnal Ilmiah Teologi, 1(1), 14-22. Retrieved from http://jurnalsttkharisma.ac.id/index.php/Kharis/ article/view/5

Mustika, M. B., \& Objantoro, E. (2020b). Pemanfaatan Mazmur 57 Dalam Konseling Krisis di Masa Pandemi COVID-19. Davar: Jurnal Teologi, 1(1), 1-8. Retrieved from http://e-

journalsangkakala.ac.id/index.php/DJT/article/ view/1

Nadilla, S. (2020). Krisis Covid-19: Perspektif Hukum Internasional terhadap Pandemi. Majalah Hukum Nasional, Badan Pembinaan Hukum Nasional, Kemenhumham RI.

Napitupulu, L. (2017). Pemahaman Dokter-Dokter Kristen mengenai Pola Pelayanan Yesus dalam Menyembuhkan Penderita Penyakit Kronis dan Penerapannya di RSUD Tugurejo Semarang. Sekolah Tinggi Teologi Baptis Indonesia.

Novira, N., Iskandar, R., \& Bahraen, R. (2020). Persepsi Masyarakat Akan Pentingnya Social
Distancing Dalam Penanganan Wabah Covid19 Di Indonesia. Jurnal Kependudukan Indonesia, Juli 2020(Edisi Khusus Demografi dan Covid-19), 27. https://doi.org/10.14203/jki.v0i0.573

Nurita, D. (2020). Aturan Baru: Anak-anak dan Lansia Dilarang ke Rumah Ibadah. Nasional.Tempo.Co.

Patandean, Y. E. (2018). Pengajaran Tuhan Yesus Mengenai Berbahagia Dalam Matius 5:3-12. Evangelikal: Jurnal Teologi Injili Dan Pembinaan Warga Jemaat, 2(2), 115-134. https://doi.org/10.46445/ejti.v2i2.103

Pura, P. A. (2020). Angkasa Pura Airports New Normal Protocol. Jakarta.

Ramadhan, R. (2020). Update Sebaran Corona Indonesia di 34 Provinsi Kamis 29 Oktober 2020. Retrieved from ZONABANTEN.com website: Zonabanten.pikiranrakyat.com/nasional/pr-23885558

Rohman, A., \& Larasati, D. C. (2020). Standar Pelayanan Publik di Era Transisi New Normal. REFORMASI: Jurnal Ilmiah Ilmu Sosial Dan Ilmu Politik, 10(2), 151-163. https://doi.org/10.33366/rfr.v10i2.1952

Ruswanto, W. (2016). Modul 1 Ruang Lingkup Ilmu Antropologi. In Buku Materi Pokok Pengantar Antropologi (ISIP4210) (1 Cet. 11, pp. 1-46). Tangerang Selatan: Penerbit Universitas terbuka.

Siagian, T. H. (2020). Mencari Kelompok Berisiko Tinggi Terinfeksi Virus Corona dengan Discourse Network Analysis. Jurnal Kebijakan Kesehatan Indonesia: JKKI, 09(02), 98-106. https://doi.org/10.22146/jkki.55475

Simorangkir, S. L. B. L. (2020). Memahami Penerapan Taurat Pada Masa Yesus dan Implikasinya Dalam Menghayati Firman Tuhan Pada Masa Kini. Jurnal Teologi Berita Hidup, 3(1), 16-32. https://doi.org/10.38189/jtbh.v3i1.55

Siregar, L. (2002). Antropologi dan Konsep Kebudayaan. Jurnal Antropologi Papua, 1(1), 3-8. 
Sukma, P. (2015). Antropologi Kesehatan. Retrieved from blog.unnes.ac.id website: http://blog.unnes.ac.id/prestia/2015/11/04/antro pologi-kesehatan/

Sumakul, N. M. (2020). Pandemi Covid-19 dalam Perspektif Alkitab dan Dampaknya bagi Kehidupan Manusia. Jurnal Teologi RAHMAT, 6(1), 1-12.

Thiessen, H. C. (1989). Anthropology in Lectures in Systematic Theology. Michigan: William B Eerdmans Publishing Company, Grand Rapids.

Trinugroho, A. T. (2020). Tatanan Ekonomi Baru. Harian Kompas, Senin 162020.

Tumbel, D. (2016). Kristologi Dalam Injil Sinoptik. Jurnal Teologi \& Pelayanan KERUSSO, 1(2), 42-56.

https://doi.org/10.33856/kerusso.v1i2.45

Umagapi, J. L., \& Sanur L, D. (2020). Peran Tim Pengawas dan Satuan Tugas DPR RI Dalam Menghadapi Pandemi Covid-19. Info Singkat: Kajian Singkat Terhadap Isu Aktual Dan Strategis.

Wijaya, H., \& Darmawan, I. P. A. (2019, December 7). Optimalisasi Superego dalam Teori Psikoanalisis Sigmund Freud untuk Pendidikan
Karakter. https://doi.org/10.31219/osf.io/zmt6y Wuryandani, D. (2020). Dampak Pandemi Covid-19 terhadap Pertumbuhan Ekonomi Indonesia 2020 dan Solusinya. InfoSingkat, Pusat Penelitian Badan Keahlian DPR RI, Volume 12. Yuliana, Y. (2020). Corona virus diseases (Covid19): Sebuah tinjauan literatur. Wellness And Healthy Magazine, 2(1), 187-192. https://doi.org/10.30604/well.95212020

Zaluchu, S. (2017). Penderitaan Kristus Sebagai Wujud Solidaritas Allah Kepada Manusia. DUNAMIS: Jurnal Teologi Dan Pendidikan Kristiani, 2(1), 61-74. https://doi.org/10.30648/dun.v2i1.129

Zaluchu, S. E. (2020). Strategi Penelitian Kualitatif dan Kuantitatif Di Dalam Penelitian Agama. Evangelikal: Jurnal Teologi Injili Dan Pembinaan Warga Jemaat, 4(1), 28-38. https://doi.org/10.46445/ejti.v4i1.167

Zaluchu, S. E. (2021). Metode Penelitian di dalam Manuskrip Jurnal Ilmiah Keagamaan. Jurnal Teologi Berita Hidup, 3(2), 249-266. https://doi.org/10.38189/jtbh.v3i2.93 